\title{
Bio-intensive integrated management strategy for mustard aphid Lipaphis erysimi Kalt. (Homoptera: Aphididae)
}

\author{
Sunita Yadav* and S. P. Singh \\ Department of Genetics and Plant Breeding, CCS Haryana Agricultural University, Hisar-125 001 (Haryana), INDIA \\ *Corresponding author. E-mail: sunitayadav10@rediffmail.com \\ Received: December 20, 2014; Revised received: March 13, 2015; Accepted: March 31, 2015
}

\begin{abstract}
Among the various treatments evaluated for their bio-efficacy against mustard aphid on Indian mustard during 2011-12 and 2012-13 at CCS Haryana Agricultural University, Hisar, the spray of Dimethoate 30 EC @ 1 ml/l followed by Verticillium lecanii @ $10^{8} \mathrm{CS} / \mathrm{ml}$ was proved to be the best treatment with pooled mean aphid population of 4.5, 3.25 and 1.65 aphids/plant as against 22.0, 24.0 and 26.0 aphids/plant in the control after 3,7 and 10 days of treatment, respectively. The pooled mean seed yield was also maximum (1485.0 kg/ha) in this treatment as compared to control $(1305.0 \mathrm{~kg} / \mathrm{ha})$.The treatment was found on par with spray of dimethoate @ $1 \mathrm{ml} / \mathrm{l}$ followed by Coccinella septempunctata @ 5,000 beetles/ha with pooled mean aphid population of 5.0, 4.0 and 2.0 aphids/plant after 3, 7 and 10 days of treatment, respectively and pooled mean seed yield of (1470.0 kg/ha). But the cost benefit ratio was maximum (7.25) in treatment dimethoate followed by $C$. septempunctata and NSKE @ $5 \%$ followed by $C$. septempunctata @ 5,000 beetles/ha (6.68). Thus, entomopathogenic fungi like V. lecanii or NSKE along with release of $C$. septempunctata can be used as alternative measure to manage mustard aphid instead of solely relying on insecticides.
\end{abstract}

Keywords: Brassica, Coccinella septempunctata, Dimethoate, NSKE, Verticillium lecanii

\section{INTRODUCTION}

Rapeseed-mustard (Brassica spp.) are the major Rabi oilseed crops, grown over an area of 6.34 million hectare with a production of 7.82 million tones and productivity of $1234 \mathrm{~kg} / \mathrm{ha}$ in 2012-13 in India (Thomas et al., 2014). More than 43 species of insect pests infest rapeseed-mustard crop in India, out of which about a dozen of species are considered as major pest (Singh, 2009). Among them aphid species i.e. Lipaphis erysimi Kalt., Brevicornae Brassicae L. and Myzus persicae Sulzer are the key pest (Desh Raj 1996; Sarangdevot et al., 2006) resulting into qualitative and quantitative yield losses. Among aphids, mustard aphid, Lipaphis erysimi (Hemiptera: Aphididae) is predominant and is a key pest of rapeseed and mustard causing up to 96 per cent yield losses and 5-6\% reduction in oil content (Shylesha et al., 2006). Such losses may go upto $100 \%$ in certain mustard growing regions (Aamir and Khalid, 1961; Singh and Sachan, 1999). Both nymph and adult stages of this pest caused economic damage by sucking the cell sap from leaves, petioles, tender stems, inflorescence and pods (Srivastava, 2002). Due to continuous desaping by large aphid population yellowing, curling and subsequent drying of leaves take place, which ultimately leads to formation of weak pods and undersized seeds in the pods. The aphids also secrete the honeydew which provides suitable medium for the development of sooty mould which ultimately hampers the process of photosynthesis
(Bakhetia and Sekhon, 1989).

A number of chemical insecticides have been found effective against this pest in different parts of the country (Singh et al. 2009; Mandal et al., 2012; Singh et al., 2014). But chemical insecticides are not only toxic to natural enemies of aphid such as Diaeretiella rapae, Chrysoperla zastrowi arabica, coccinellids and syrphid flies (Nagar et al., 2012), but these are also responsible for environmental pollution, health hazards to human beings, toxic to pollinators, pest resurgence, development of resistance in insect-pests and residues in oil and cake (Singh, 2001). Therefore, it is necessary to find eco friendly methods for managing mustard aphid to protect the natural enemies and pollinators as well as human health. Keeping the above facts in mind the present investigation was undertaken to evaluate the bio-intensive integrated management strategy for effective control of L. erysimi.

\section{MATERIALS AND METHODS}

The present investigation was carried out at Research Area of Oilseeds Section, Department of Plant Breeding and Genetics, CCS Haryana Agricultural University, Hisar during Rabi seasons of the year 2011-12 and 2012-13. Experiment was conducted in a completely randomized block design with ten treatments including control and replicated thrice with plot size of $4.2 \times 3 \mathrm{~m}$ on mustard cv. RH 30. The crop was sown during first fortnight of November with row to row and plant to plant as $30 \mathrm{~cm}$ and $10 \mathrm{~cm}$ respectively and all the standard 
agronomic practices were followed to raise the good crop. Ten treatments including control were $\mathrm{T}_{1}$ : Verticillium lecanii@108 CS/ml followed by Coccinella septempunctata @ 5,000 beetles/ha, T2: V. lecanii@10 $10^{8} \mathrm{CS} / \mathrm{ml}$ followed by NSKE@5\%, T3:V.lecanii@10 $10^{8} \mathrm{CS} / \mathrm{ml}$ followed by Dimethoate@1 ml/1, T4: NSKE@5\% followed by C. septempunctata@5,000 beetles/ha, T : NSKE@5\% followed by $V$. lecanii@10 CS/m, T6: Neem oil@2\%\% followed by C.septempunctata@ 5,000 beetles/ha, T7: Neem oil@2\% followed by $V$. lecanii@10 $10^{8} \mathrm{CS} / \mathrm{m}, \mathrm{T}_{8}$ : Dimethoate@ 1 ml $/ \mathrm{l}$ followed by C. septempunctata@5,000 beetles/ha, T9: Dimethoate@1 ml/1 followed by V.lecanii@10 $10^{8} \mathrm{CS} /$ $\mathrm{m}$ and T10: Control with no spray. The population of aphids was counted from ten randomly selected plants from each plot one day before and 3, 7, and 10 days after spray of insecticides. The aphids were counted from the top $10 \mathrm{~cm}$ apical twigs of these selected plants with the help of a magnifying glass by tally counter. The numbers of aphids / plant were converted into \% reduction of aphid population over the control. Yield was recorded from net plot area and converted in to kilogram per ha and data were statistically analyzed in appropriate programme in a Randomized Block Design (RBD) as outlined by Gomez and Gomez (1976). The incremental cost benefit ratio was calculated by prevailing market price of mustard seed, cost of insecticides and labour used with the following formula.

Cost benefit ratio $=$ Additional profit over the control - Cost of treatment

\section{RESULTS AND DISCUSSION}

Pooled mean aphid population in pre treatment observations was homogenous throughout the experimental field and ranged from 17.75 to 18.95 aphids $/ 10 \mathrm{~cm}$ main apical shoot (Table 1). Overall mean of the data indicated a significant difference among the treatments and control. Data recorded on $3^{\text {rd }}$ day after application revealed that aphid population was decreased in every treatment except untreated plot. Treatment T9 (Dimethoate 30 EC@ 1 ml/1 followed by $V$. lecanii @ 10 $10^{8} \mathrm{CS} / \mathrm{ml}$ ) proved most effective with minimum number of aphids (4.50 aphids/plant) and it was on par with T8 (Dimethoate 30 EC@ @ 1 ml/1 followed by C. septempunctata (a) 5,000 beetles/ha). Both the treatments were significantly $(\mathrm{p}=0.05)$ superior over rest of the treatments. Treatment $\mathrm{T}_{3}$ (V.lecanii@108 CS/ml followed by Dimethoate@ $1 \mathrm{ml} / \mathrm{l})$ was found to be the next effective treatment (7.50 aphids/plant) and differ significantly from rest of the treatments. In all other treatments, i.e.V.lecanii@ $10^{8} \mathrm{CS} / \mathrm{ml}$ followed by $C$. septempunctata@5,000 beetles/ha, V.lecanii@10 $10^{8} \mathrm{CS} / \mathrm{ml}$ followed by NSKE @ 5\%, NSKE@5\% followed by C. septempunctata (a) 5,000 beetles/ha, NSKE@5\% followed by $V$. lecanii (a) $10^{8} \mathrm{CS} / \mathrm{m}$, Neem oil @ 2\%\% followed by $C$. septempunctata@5,000 beetles/ha and Neem oil@ 2\% followed by V.lecanii @10 CS/m aphid population ranged from 10.50 to 12.00 and were on par with each other. Maximum aphids (22.00 aphids) were recorded in control plot. Kumar and Singh (2009) reported that use of $V$. lecanii alone provided good aphid control and also in combination with $C$. carnea and oxy-demeton methyl. These studies support the present investigation.

Data recorded on seventh day after spray also showed decreased pattern of aphids in all the treatments except control plot. The minimum aphid population (3.25 aphids) was again observed in Dimethoate @ 1 ml/1 followed by $V$. lecanii@ $10^{8} \mathrm{CS} / \mathrm{m}$ treatment and it was on par with Dimethoate @ $1 \mathrm{ml} / 1$ followed by $C$. septempunctata@5,000 beetles/ha treatment (4.00 aphids) and $V$. lecanii @ $10^{8} \mathrm{CS} / \mathrm{ml}$ followed by Dimethoate@1 ml/1 treatment (5.0 aphids). In all other treatments (T1, T2, T4, T5, T6 and T7) aphid population ranged from 7.50 to 10.00 and were on par with each other. Maximum aphids (24.00 aphids) were recorded in control plot.

Again the aphid population after 10 days of spray was minimum (1.65) in Dimethoate@1 ml/1 followed by V.lecanii@108 CS/m treatment and it was on par with Dimethoate@1 ml/1 followed by C. septempunctata (a) 5,000 beetles/ha treatment (2.00 aphids), V. lecanii (a) $10^{8} \mathrm{CS} / \mathrm{ml}$ followed by Dimethoate @ $1 \mathrm{ml} / 1$ treatment (3.0 aphids) and V. lecanii @10 $10^{8} \mathrm{CS} / \mathrm{ml}$ followed by NSKE@ $@$ \% treatment (5.00 aphid). In all other treatments aphid population ranged from 7.00 to 8.50 and significantly better over control (26 aphids).

The per cent reduction of aphid population after 10 days of spray was maximum under Treatment T9: Dimethoate 30 EC@1 ml/1 followed by V. lecanii@ $10^{8} \mathrm{CS} / \mathrm{m}(90.96 \%)$ followed by T8: Dimethoate 30 EC@1 ml/1 followed by C. septempunctata@5,000 beetles/ha (89.19\%) and T3: NSKE@5\% followed by C. septempunctata@5,000 beetles/ha (83.70\%). Minimum reduction in aphid population was recorded in treatment T5: Neem oil@2\% followed by Chrysoperla carnea @ 50,000 larvae/ha followed by T4: NSKE@5\% followed by V.lecanii @ 10 ${ }^{8} \mathrm{CS} / \mathrm{m}$ and T7: Neem oil @ 2\% followed by V. lecanii @ 10 $0^{8} \mathrm{CS} / \mathrm{m}$. Singh et al., (2009) found that C. septempunctata@ @wo adults/plant were effective in reducing $96.19 \%$ of the aphid population in 10 days followed by $C$. septempunctata @ two larvae per plant (93.42\%) and V.lecanii @ 10 spores/ml $(84.90 \%)$.

The maximum crop yield $(1485 \mathrm{~kg} / \mathrm{ha})$ was recorded in treatment T9 (Dimethoate@ $1 \mathrm{ml} / \mathrm{l}$ followed by $V$. lecanii@108 $\mathrm{CS} / \mathrm{m}$ ) and it was found to be on par with treatment T8 (Dimethoate@1 ml/1 followed by $C$. septempunctata@5,000 beetles/ha) (1470 kg/ha), whereas minimum yield (1305 kg/ha) was recorded in control. These results coincide with the findings of Singh and Singh (2009) who observed a significantly higher yield of mustard seed under dimethoate $30 \mathrm{EC}$ (a) 300 g a.i./ha.. Sinha et al. (2001) also reported dimethoate was moderately toxic to mustard aphid in field condition and increase the yield of mustard. Singh et al. (2008) evaluated V. lecanii @ 10 $0^{8}$ spores $/ \mathrm{ml}$ of water 
Sunita Yadav and S. P. Singh / J. Appl. \& Nat. Sci. 7 (1) : 192 - 196 (2015) 
against mustard aphid in the field and found some promising results provided sufficient relative humidity in the atmosphere. Singh and Meghwal (2010) reported that maximum yield was recorded in C. septempunctata@ 5,000 beetles/ha followed by V.lecanii@10 $\mathrm{CS} / \mathrm{ml}$ and C. septempunctata@3,000 beetles/ha.

The highest BCR (7.25) was obtained from Dimethoate @ $1 \mathrm{ml} / 1$ followed by C. septempunctata@5,000 beetles/ ha treated plots followed by NSKE@5\% followed by $C$. septempunctata@5,000 beetles/ha (6.68), Dimethoate @ 1 ml/1 followed by Verticillium lecanii@10 $10^{8} \mathrm{CS} / \mathrm{m}$ (2.75), NSKE@5\% followed by V.lecanii@10 $10^{8} \mathrm{CS} / \mathrm{m}$ (2.20) and neem oil @ 2\%\% followed by $C$. septempunctata (a) 5,000 beetles/ha (2.20). The lowest BCR was obtained from Neem oil @, 2\% followed by V. lecanii @ 10 $0^{8} \mathrm{CS} / \mathrm{m}$ treated plots (1.37),V. lecanii@10 CS/ml followed by NSKE@5\%(2.04) and V.lecanii@10 CS/ml followed by Dimethoate@1 ml/1 (2.06) (Table 2). Akhauri and Singh (2009) studied the bio-efficacy of some insecticides and bio-products against mustard aphid, L. erysimi (Kalt.) in yellow sarson and found that highest return (1:24.6) were obtained in NSKE @ 5\% followed by dimethoate 30EC (22.7), imidacloprid 17.8\% SL (19.4), betacyhalothrin (18.1), neem oil (15.9), endosulfan (14.4) and diflubenzuron (9.0). Singh and Singh (2009) observed a favourable cost-benefit ratio under the treatments i.e. dimethoate 30 EC @ $300 \mathrm{~g}$ a.i./ha against L. erysimi. These results are in corroboration with the present study. Meena et al. (2013) evaluated microbial agents and bio-products for the management of $L$. erysimi and found the most favourable cost-benefit ratio under the treatment i.e. dimethoate 30 EC @ $300 \mathrm{~g}$ a.i/ha (1:38) followed by neem seed kernel extract@5\%(1:18).

\section{Conclusion}

From the above discussion it may be concluded that among the tested treatments, Dimethoate @ $1 \mathrm{ml} / 1$ followed by $C$. septempunctata@5,000 beetles/ha and NSKE@ 5\% followed by C. septempunctata@ @,000 beetles/ha may be recommended for most economic and effective management of mustard aphid, Lipaphis erysimi on rapeseed mustard crop.

\section{REFERENCES}

Aamir, K. and Khalid, M. (1961). Insect pests attack on rapeseed. Jalal Publisher, Lahore, 200 pp.

Akhauri, R.K. and Singh, N.K. (2009). Bio-efficacy of some insecticides and bio-products against mustard aphid, Lipaphis erysimi (Kalt.) in yellow sarson. Journal of Oilseed Research, 26: 456-457.

Bakhetia, D.R.C. and Sekhon, B.S. (1989). Insect-pests and their management in rapeseed-mustard. Journal of Oilseeds Research, 6: 269-299.

Desh, R., Devi, N., Singh, A.B. and Verma, S.C. (1996). Relative susceptibility of germplasms of three cruciferous oilseed crops to three different aphid species and chemical basis of their differential reactions. Journal of Entomological Research, 20(2): 115-120.

Gomez, K.A. and Gomez, A.A. 1976 Statistical procedures for agricultural research with emphasis on rice. IRRI, Los Baños, Philippines. 264 p.

Mandal, D., Bhowmik, P. and Chatterjee, M.L. (2012). Evaluation of new and conventional insecticides for the management of mustard aphid, Lipaphis erysimi Kalt. (Homoptera: Aphididae) on rapeseed (Brassica juncea L.) The Journal of Plant Protection Sciences, 4(2): 37-42

Meena, H., Singh, S.P. and Nagar, R. (2013). Evaluation of microbial agents and bio-products for the management of mustard aphid, Lipaphis erysimi (Kalt.) The Bioscan, 8(3): 747-750

Nagar, A., Singh, S.P., Singh, Y.P., Singh, R., Meena, H. and Nagar, R. (2012). Bioefficacy of vegetable and organic oils, cakes and plant extracts against mustard aphid Lipaphis erysimi (Kalt.). Indian Journal of Entomology, 74(2): 114-119

Sarangdevot, S.S., Kumar, A. and Chundawat, G.S. (2006). Field bio-efficacy of some newer insecticides against aphids infesting tomato crop. Pestology, 30(3): 20-22.

Shylesha, A.N., Azad Thakur, N.S., Pathak K.A., Rao K.R., Saikia K., Surose, S., Kodandaram, N.H. and Kalaishekar, A. (2006). Integrated management of insect pest of crops in north eastern hill region. Technical Bulletin No. 19. ICAR RC for NEH Region, Umiam, 50p

Singh, P.K. (2001). Control of mustard aphid, Lipaphis erysimi (Kalt.) (Homoptera: Aphididae) with minimum insecticide use. Journal of Aphidology, 15: 139-42.

Singh, D.K., Pal, S., Dwivedi, R.K. and Pal, R.K. (2014). Efficacy of insecticides against Mustard aphid, Lipaphis erysimi Kalt. Annals of Plant Protection Sciences, 22 (1):39-41

Singh, C.P. and Sachan, G.C. (1999). Eco-friendly management of Lipaphis erysimi Kalt. in Brassica carinata. Proceeding of $10^{\text {th }}$ International Rapeseed Conference, Canberra, Australia.

Singh, S.P. (2009). Insect pest management in oilseed crops. Indian farming, 58 (7):29-33

Singh, S.P. and Singh, Y.P. (2009). Bio-efficacy of pesticides against mustard aphid. Annals of Plant Protection Sciences, 17: 240-242.

Singh, Y.P., Meghwal, H.P. and Singh, S.P. (2009). Evaluation of some bioagents against Mustard Aphid (Lipaphis erysimi (Kaltenbach) (Hemiptera: Aphididae) on single plant in field condition. Journal of Biological Control, 23 (1): 95-97.

Singh, Y.P., Singh, S.P. and Meghwal, H.P. (2008). Evaluation of bioagents against mustard aphid, Lipaphis erysimi (Kalt.) (Homoptera: Aphididae), under net covered condition in field. Journal of Biological Control, 22: 321-326.

Singh Y.P. and Meghwal H.P. (2010). Evaluation of some bioagents against mustard aphid (Lipaphis erysimi kaltenbach) (Homoptera: Aphididae) under field conditions. Indian Journal of Entomology, 72(1): 66-70

Sinha, R.P., Kumari, K. and Singh, S.N. (2001). Relative efficacy and persistence of toxicity of insecticides against mustard aphid. Indian Journal of Entomology, 63 (2): 186-91.

Srivastava, A. (2002). Nefarious pests of rapeseed-mustard. The tribune (On line edition) Chandigarh. India.

Thomas, L., Sharma A.K. and Singh D. (2014). Strategies for enhancing rapeseed mustard production in Rajasthan. Directorate of rapeseed-mustard research, Sewar, Bharatpur 3213003, Rajasthan, India. pp 44 